\title{
The Unbearable Lightness of A Useful Knowledge and Economic Growth Thráinn Eggertsson ${ }^{1}$
}

JEL: O3, P51, K1, B1, B52.

Key concepts: Physical and social technologies, useful knowledge, neoclassical growth theory, industrial revolutions, the Enlightenment, property rights and technical change.

\section{Introduction}

Economists usually sing with the same nose when they answer questions about the role of technology in economic growth. They generally agree that sustained longterm growth in productivity, which began in Western Europe some two centuries ago, could not have been maintained in an environment of stagnant production technologies. Whether we consult Karl Heinrich Marx, Joseph Alois Schumpeter or Robert Merton Solow, the answer is the same: new technologies are the source of long-term economic growth. Economists, as we know, usually argue that the production and utilization of new technologies depend critically on appropriate social institutions, such as competition, decentralized markets, secure property rights, enforceable contracts, and norms of trust and reciprocity. Yet virtually no one argues that long-term growth in output per worker is possible in an economy with stationary production techniques. ${ }^{2}$

In his pioneering contribution to modern (neo-classical) growth theory, Solow (1956; 1957) uses the letter $A$ to represent technology. Specifically, in Solow-type growth models the letter $A$ symbolizes the stock of technology, which for convenience is assumed to increase with time at a fixed rate. If the exogenous increase in $A$ is assumed to be labor saving, it means that technical change makes it possible to produce a given level of output by using fewer labor units than before and the same amount of capital. In equation (1) $y$, average output per capita for an economy, is a function of the state of technology, $A$, and the ratio of capital to labor, $k$ :

$$
y_{t}=A_{t} \cdot k_{t}^{\alpha}
$$

1 Thráinn Eggertsson is a Professor at the Iceland School of Business, University of Iceland, and a Global Distinguished Professor, Department of Politics, New York University. The Paper was presented at the symposium in honour of Professor Gudmundur Magnusson, University of Iceland, Reykjavik, November 2007.

2 Growth laggards are of course able to increase output per worker by simultaneously reforming their social institutions and obtaining foreign technologies from abroad. Longterm growth, however, requires new additions to the stock of existing knowledge and technologies. 
In any time period, $t$, output per unit of labor, $y_{t}$, is determined by the value of the capital-labor ratio, $k_{t}$. Note that $A_{t}$ is fixed as well as the technical parameter $\alpha$, which is a positive fraction. With $A_{t}$ and $\alpha$ given, there exists an optimal value for $k_{t}$ that maximizes output per unit of labor (or income per capita). In a competitive economy with flawless market institutions, the forces of supply and demand spontaneously establish global equilibrium involving optimal value for $k$. If for some reason the autonomous increase in $A$ would come to an end, in Solow growth models the assumption of sharply diminishing marginal product of capital takes away the possibility of propelling long-term growth of $y$ via capital accumulation (by steadily raising $k$ ). Finally, Solow's growth theory is admired for its formal elegance and bold predictions, particularly the famous convergence hypothesis, which states that in the long run, regardless of their starting points, all economies will converge on the same per-capita income, $y$, and realize the same steady-state rate of growth.

It is well known that in modern times economic growth has not equalized living standards around the world but instead opened an extraordinary income gap between rich and poor countries. If at time $t$ all countries share the same technology, $A$, as the Solow model assumes, in theory differences in incomes per capita must be caused by country differences in the capital-labor ratio, $k$. In practice, we cannot use the variation between countries in $k$ ratios to explain the income gap. Given a range of values for $\alpha$ in equation (1) that is empirically reasonable, differences in $y$ between rich and poor countries can only be explained by assuming absurdly large differences in their capital-labor ratio, $k$ (Romer, 1994). We therefore must either throw away the Solow approach or modify the assumption that all countries share the same $A_{t}$. But now we have a new problem. Neoclassical growth theory assumes that $A$, technical knowledge, is a pure public good that is instantly available to all nations. To escape the quandary we can recognize $A$ as having many attributes of an international public good (non-excludable and non-rival) but as being strongly dependent for its effects upon specific complementary goods: appropriate social institution. Moreover, we can argue that, unlike $A$, social institutions are generally local public goods with weak international public goods properties. ${ }^{3}$ Along these lines, in a recent book I distinguish between social technologies and production technologies (Eggertsson, 2005). The concept "social technologies" refers to knowledge or understanding of the social mechanisms that give institutions their properties. Social institutions are bundles containing several elements: formal rules, social norms, beliefs, and enforcement mechanisms. The term "social technologies" implies knowledge of how institutions emerge, how they function and how they change (spontaneously or by design). It is fair to say that we have more knowledge of physical technologies than social technologies, and in the domain of social technologies we know more about static than dynamic properties of institutions. We know more about the market response to harvest failures than about the path from insecure to secure property rights.

3 For instance, shared history and common characteristics make it relatively easy for the Scandinavian countries to import laws and regulations from each other. Countries far away from the Scandinavian perimeter, however, would find it harder to import the same bundles of rules and enforcement mechanisms and put them to effective use. 
In sum: Long-term increase in $A$ is the basic source of a sustained rise in living standards but only when new production techniques are supported by complementary social institutions-and therefore by appropriate incentives. The application of new production techniques usually requires investment in physical and human capital, which will not be forthcoming in the absence of secure property rights, enforceable contracts, and supportive organizations. Moreover, appropriate institutions and incentives are required for creating new knowledge. New knowledge and new methods of production are scarce assets that are costly to produce. Also, it is important to note that new knowledge, even new technical knowledge, is not always wealth augmenting. For instance, social institutions that create incentives to develop technologies for capturing resources through theft or warfare do not contribute to economic growth (at least not directly). Finally, it is fair to say that the economics of knowledge is one of the least developed branches of our science. In economic theory, $A$ has a long history of being a nondescript exogenous variable. ${ }^{4}$

\section{Social Organization and A}

A, physical technology, is a critical input both in the traditional processes of producing commodities as well as in the production of institutions such as secure property rights or enforceable contracts. At the risk of oversimplifying we can write

$$
I=f(A ; Z ; X)
$$

In equation (2) each symbol represents a vector of variables. The letter $I$ stands for the set of technically available forms of social institutions or organization, $A$ represents physical knowledge and technologies, $Z$ social knowledge and social technologies, and $X$ stands for various background factors such as geography and natural resources. Equation (2) defines the choice set of institutional forms that are theoretically available to a particular community. ${ }^{5}$ Communities select or acquire a set of social institutions, $S$, that belongs to the larger $I$ set. The empirical evidence does not give us reasons to think that communities or nations optimize in the sense of always selecting the wealth-maximizing subset $S$ from $I$. Various forces intervene, such as failures of collective action, narrow self-interests of ruling groups, beliefs, values and cognitive limitations. We argue, however, that $I$, the choice set of institutions, becomes larger as $A$ increases. It follows that a social group that only

4 Relatively few mainstream economists have extensively studied economics of science, knowledge, and technological change whereas these topics appear to be more popular among evolutionary economists (Nelson \& Winter 1982). Fritz Machlup (1962), a mainstream economist, is a classic reference. In addition to Machlup, the small but distinguished set of economists exploring the economics of knowledge contains, for instance, Adam Smith, Karl Marx, Joseph A. Schumpeter, Friedrich A. Hayek, Kenneth J. Arrow, Herbert A. Simon, and Paul A. David. So-called new or endogenous growth theory attempts to make $A$ endogenous in macroeconomic growth models. To my knowledge, the new growth literature has not yet produced important new insights into the nature of $A-$ perhaps because macroeconomic models are not a productive venue for studying the phenomenon (Nelson 1997).

5 The simple formulation in equation (2) does not recognize that the choice of new institutions is constrained by already prevailing institutions, including formal rules and social norms. 
knows and uses primitive physical technologies has relatively few choices when it comes to institutions.

Let us consider in some detail the case of primitive, isolated and preliterate farming societies. In such societies the capacity to organize is critically constrained by the limited availability of physical technologies of communication, measurement, monitoring and enforcement. Primitive societies that have a long history of survival are likely to have set up relatively efficient social institutions, $S$, given their small $I$ set, because the opportunity cost of inefficient institutions is high. Primitive societies live close to extinction and nature filters out the most inefficient ones. In a thoughtful essay Richard A. Posner (1980) works his way through organizational forms that are likely to be available in traditional societies with no written records, scant knowledge of the laws of nature, and access to only the most elementary techniques of farming and agriculture. In an ideal-type primitive society, he asks, what social institutions do we expect to find in the spheres of politics, property rights, insurance against hunger, protection of order, economic exchange and religion? Posner then appeals to high information and transaction costs to explain why preliterate and low- $A$ societies usually are stateless, lack specialized organizations such as firms and government bureaus, are elaborately organized into clans, rely on communal property rights, strict liability in torts, gift exchanges, joint or interrelated institutions for production, government, and religion, and even have institutions that block the accumulation of surpluses by fortunate individuals.

Hull \& Bold (1994) use an approach similar to Posner (1980) to explore the structure of religion in primitive societies, particularly their reliance on the promise of heaven and the threat of hell as social mechanisms for maintaining public order. In the production of social order, Hull and Bold assume diminishing returns to both threats and promises and hypothesize that primitive societies with relatively weak worldly governance mechanisms rely heavily on religion to maintain order, evoking both heaven and hell because of diminishing returns to each method. Societies with more advanced administrative control mechanisms rely either on heaven or hell, not on both. Hull and Bold (1994) then find statistical support for their thesis in an empirical test using data drawn from preliterate communities.

We conclude by suggesting two related explanations of the relatively high variance in $y, A$, and $S$ across countries in modern times. First, the emergence of growthcompatible $S$ (social institutions) is associated with the separation of political and economic institutions to a degree where (a large segment of) the population is free to enter (almost) all economic activities and compete in the economic sphere. In history, the alternative arrangement is for the rulers, in payment for political support, to allocate economic opportunities and monopoly rights directly to a small minority, the leading members of the rulers' winning coalition. Successful economic reforms require opening access to the economic sphere and providing investors with fairly secure rights. Second, reformers who rapidly overcome political barriers and attempt to move quickly by importing modern $A$ and growth-friendly $S$ come up against complementarities at two levels: the dependence of high-level $A$ on appropriate $S$; and, within the $S$-set, the dependence of imported formal institutions on preexisting local institutions, particularly on informal institutions or social norms. Imported 
constitutional, commercial, contract, and corporation laws tend to be dysfunctional unless supported by social norms involving legitimacy, trust, reciprocity, and basic standards of honesty. Informal institutions are rooted in history and do not adjust automatically to rapid changes in the environment.

In sum: Moves to qualitatively different new political equilibrium are associated with major changes in political power; and the social mechanisms governing rapid changes in social norms are poorly understood. The political balance and social norms are usually outside the reach of economic reformers (Eggertsson 2005).

\section{A. Smith and the British A Revolution}

The consensus on the critical role of $A$ in economic progress has not stimulated comparably great interest among researchers in the economics of knowledge. In fact economists (and others) are not particularly good at recognizing industrial revolutions in their early stages. ${ }^{6} \mathrm{We}$ do best when predicting technological watersheds after the fact because the consequences of general-purpose technologies, such as steam power, electricity or electronics, are essentially unforeseen or unforeseeable. Revolutionary general-purpose technologies reshape production methods, economic institutions (rules and norms), economic organizations (the structure of firms and contracts) and our life styles, but these transformations occur gradually and sequentially. At the outset, most travelers cannot see whither their path will lead.

Adam Smith first published his Wealth of Nations in 1776. The third revised edition of the book appeared in 1782, the year in which, according to the English economic historian Thomas S. Ashton (1997 [1964]), the pace of output in England quickened, ushering in the British Industrial Revolution. Yet the Industrial Revolution does not play a role in Smith's masterpiece (Koebner 1959). Smith apparently did not foresee the rise of British industry driven by mechanization of production and transport; he was not a prophet of entrepreneurship and industrialization. Unlike Schumpeter writing some 150 years later, Smith was doubtful about the contribution of daring industrial innovators and entrepreneurs, referring to them as speculators and projectors (Koebner 1959). If we want to give Smith the benefit of doubt, it is possible (but unlikely), that he understood the significance of contemporary industrial developments but for strategic reasons decided to ignore them. Smith's practical aim with the Wealth of Nations was to lay bare the economic weaknesses of the Mercantile System and promote the use of free markets. Speculations about an industrial revolution could have complicated his message. Smith's well-known argument is that economic freedom increases the size of markets, promotes specialization, raises productivity (the pin example), and improves the standard of living. Taking $A$ as given, Smith's eyes were on complementary social institutions and organizations.

6 Few issues receive greater attention in modern economic theory than the relative efficiency of various market structures but theory usually assumes stationary A when analyzing various mechanisms for allocating resources. The mainstream literature recognizes as such the concept of "dynamic efficiency," sometimes with a nod toward Joseph Schumpeter (2005, [1939]), who in his work explored the dynamics of capitalism. Yet it is fair to say that dynamic efficiency plays a trivial role in modern mainstream economic analysis. 


\section{$A$, the Enlightenment, and Modern Economic Growth}

DNA evidence indicates that humans emerged in Africa, perhaps some 200,000 years ago. Modern production technology and modern economic growth span the last 200 years or thereabouts, which equals approximately only 0.125 percent of mankind's time on earth. We know also that in the second half of the $17^{\text {th }}$ Century in Western Europe the stock of useful knowledge, the source of modern production technology, started to expand rapidly and has since then grown at an accelerating rate. Why did this happen? Why in Western Europe?

Joel Mokyr (2005a, 2005b), the distinguished economic historian who specializes in the history of knowledge and the British Industrial Revolution, associates the rapid expansion in the stock of useful knowledge during the late $17^{\text {th }}$ and $18^{\text {th }}$ centuries with the Age of Enlightenment in Europe. If new production technology is to emerge and spread rapidly within a large geographical area, two conditions are required: (a) emergence of strong incentives for producing useful knowledge, and (b) falling costs of accessing and disseminating new knowledge. Mokyr finds evidence that both conditions were present during the Enlightenment in the latter half of the $17^{\text {th }}$ and $18^{\text {th }}$ Centuries. ${ }^{7}$ The period saw the gradual redirection of a significant component the West European research program away from knowledge for its own sake with emphasis on theological and metaphysical issues toward knowledge useful for solving practical problems and raising living standards. The work and ideas of Sir Francis Bacon (1561-1626) symbolize the redirection of research toward modern science and technical change. Yet ideological incentives are only one part of the story. A scientific revolution also requires political conditions that do not punish but actually encourage those who seek practical knowledge. The travails of Galileo Galilei (1564-1642) and Giordano Bruno (1548-1600) are cases in point. We discuss the political environment below.

The latter of the two requirements is low costs of accessing new knowledge. Mokyr (2005a) documents how in the $17^{\text {th }}$ Century various methods for codifying and storing knowledge and information began to appear. The Age of Enlightenment saw a rapid increase in the publication of scientific pamphlets and periodicals; the evolution of informal networks of scholars; and the establishment of formal science academies, the first national academy being the Royal Society of London for the Improvement of Natural Knowledge, established 1660, and the second the Académie des sciences in Paris founded in 1666 by Louis XIV. Figure 1 reproduces one of the many indicators that Mokyr presents in support of his thesis: Scientific periodicals in Europe by year of first appearance.

7 Many scholars refer to the $17^{\text {th }}$ Century in Europe as Age of Reason and the $18^{\text {th }}$ Century as Age of Enlightenment. Others, as is done here, use the term Age of Enlightenment to represent the entire two hundred year period. 
Figure 1. Intellectual Origins.

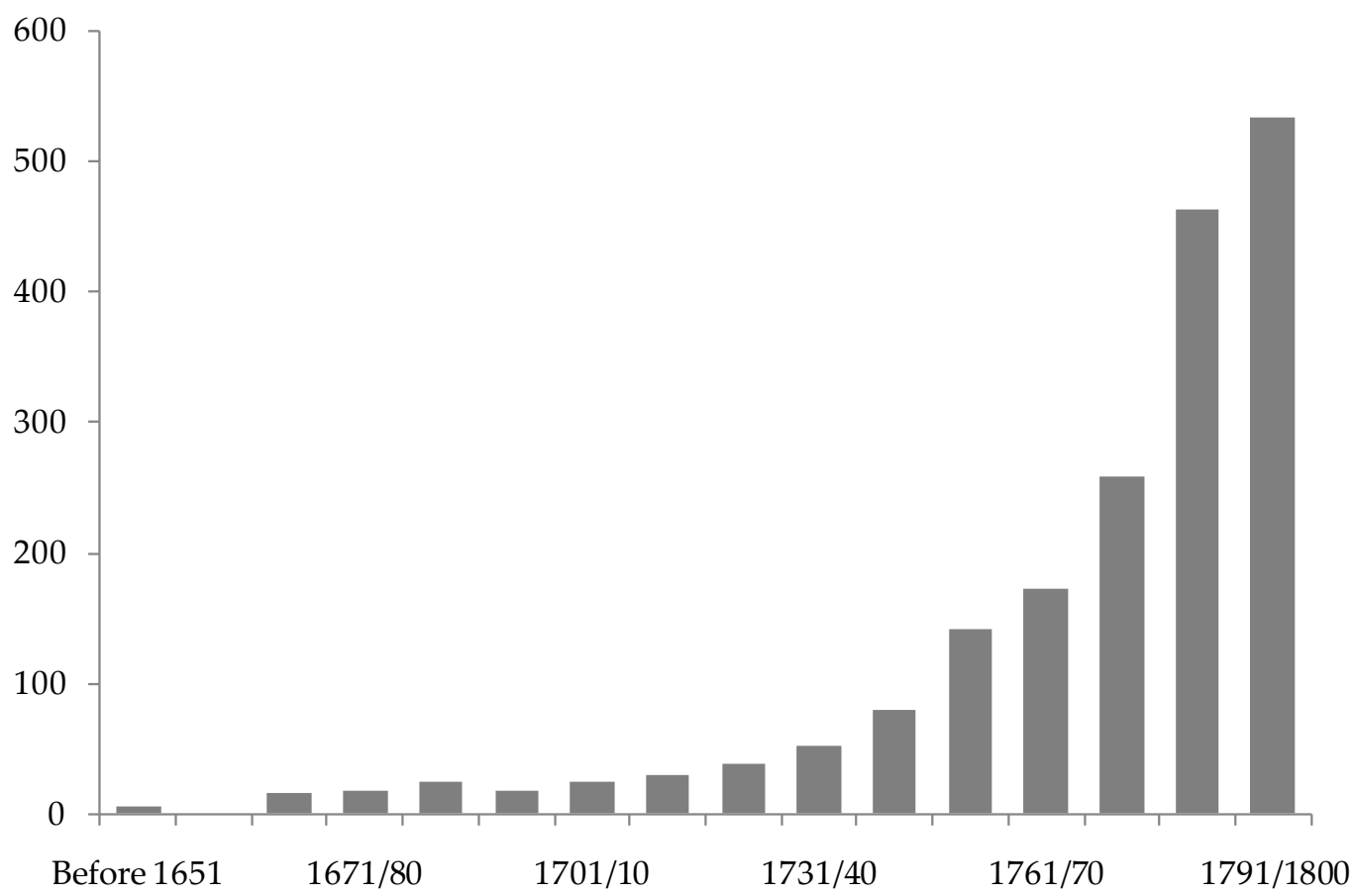

Scientific Periodicals by Year of First Appearance

Source: Computed from Kronic, Scientific and Technical Periodicals.

Figure 1 shows that until around 1650 virtually no scientific periodicals had appeared; in the period 1741-50 approximately 100 new periodicals appear; and during the years 1791-1800 the number of new periodicals exceeds 500 .

The evidence is hardly in doubt. Several reliable indicators show that in Western Europe during the Age of Enlightenment the production of useful knowledge surged and the costs of access fell. We have already mentioned the symbolic role of Francis Bacon in emphasizing useful knowledge. Yet an important issue remains unexamined: the political dimension. Why did the ruling elites of Western Europe tolerate relatively free scientific inquiry? In history, powerful rulers have been wary of new ideas about the social, spiritual and physical worlds and tried to control or repress scholarship. The rulers fear with some reason that unbridled new ideas may undermine the status quo and challenge their authority. What developments then opened a window of opportunity for independent scholarship in Western Europe in the late $17^{\text {th }}$ and $18^{\text {th }}$ Centuries? Mokyr (2005b) finds the answer in the political fragmentation of the region.

In this period Western Europe was politically fragmented and without an overarching and synchronizing center of power because of the diminished role of the Catholic Church. ${ }^{8}$ With central authority absent, intellectuals and scholars who felt threatened by their local authorities had the option of moving between political units and playing one regime against another. Again Mokyr (2005b) presents data, now recording the movement of European intellectuals and scholars between European

8 For instance, when Germany under the leadership of Prussia emerged as a nation state in 1871, it was through the unification of 39 independent states. 
political units during the Enlightenment period. The data show high rates of mobility of scholars between European centers of learning but toward the end of the period mobility rates appear to fall in spite of a sharp reduction in transportation costs. Mokyr associates the decline in mobility with a gradual increase in the tolerance of new ideas in Western Europe, which would have lowered the demand for political refuge. ${ }^{9}$

The exponential rise of science and useful knowledge during the Enlightenment is often associated with the social norm of "open science", which emerged in this period, replacing the institution of secrecy, which was the dominant strategy of medieval craft guilds as well as of scholars in general. ${ }^{10}$ The economic rationale of secrecy was comparable to the motives behind the current phenomenon of trade secrets: they are attempts to privatize or internalize knowledge. The term "open science" involves the practice of pursuing knowledge for its own sake (rather than for strategic motives), sharing findings with other members of the scholarly community, and submitting findings to peer reviews. Using my term, open science is a social technology with a history of being effective mechanism for organizing the production of scientific knowledge. Paul David (2007), the distinguished expert on the economics of science and technology, offers an interesting explanation of the historical origins of open science, which overlaps partly with Mokyr's (2005b) study of the intellectual origins of modern economic growth. Once again the argument centers on political fragmentation in early modern Europe, but David focuses his explanation on competition among princes and elites who sought prestige by surrounding themselves at court with artists, writers and scholars. A brief account of David's elaborate thesis must necessarily leave out many of his theoretical arguments and historical detail, including an elaborate explanation of the emergence in the late $17^{\text {th }}$ Century of formal scholarly societies and academies. His main argument, however, focuses on information asymmetry and problems of agency in the relationship between scientists or natural philosophers and their elite patrons.

The $16^{\text {th }}$ and $17^{\text {th }}$ Centuries saw explosive growth in mathematical ideas. Leading scholars became increasingly involved with basic research in mathematics, which advanced rapidly, and moreover, natural scientists came to favor the language of mathematics in their studies. These producers of a public good, knowledge, needed somehow to make a living and the evolving system of court-patronage of the arts and sciences was a major source of support. In fragmented Western Europe competition among the princes for respect and awe took many forms. The princes built magnificent palaces and public buildings; they supported sculptors, painters and musicians and displayed their art; and they served as patrons to the prominent scientists of the day. However, the new math aggravated the information asymmetry between scientists and their patrons. The princes and their advisers were incapable

9 Greater tolerance of scholars toward the end of the period could be related to rising opportunity cost of oppressing science and technology as the value of new discoveries steadily increased and became more obvious.

10 Robert K. Merton (1973) in his book The Sociology of Science provides a classic analysis of the social norms that govern open science in an ideal world. He identifies four norms: universalism, communism, disinterestedness, and organized skepticism. 
of evaluating scholars who used complex mathematics, which meant for the elites that their risk of offering patronage to charlatans had substantially increased. ${ }^{11}$ David (2007) theorizes that the social norm of open science and peer review emerged to ease the measurement problem of overseeing scholars. Facing serious problems in measuring directly the quality of scholarly services, the elites were willing to support the norm of open science and rely (at least partly) on indirect measurement by the scholarly community or peer review. Yet direct measurement did not entirely disappear. The circumstances sometimes permitted the rulers to get direct impressions of the importance of scientific findings. David (2007) cites the case of Galileo Galilei who advanced his career by strategically presenting rulers with powerful telescopes, a new invention, so they could see for themselves. It has even been suggested that Galileo's troubles with the church were brought on not only by the Jesuit Order but also by fellow professors who were jealous of Galileo's aggressive pursuit of patrons and his successful career moves (David 2007, 44-49; Westfall 1985).

The Mokyr mechanism for allowing scholars to avoid political repression and the David mechanism for lowering the cost of agency are not mutually exclusive explanations of the rise of $A$; in fact the two explanations reinforce each other. Not all rulers would see scholar $X$ or discovery $Y$ as a threat to their regime; scholars who felt threatened could exploit the elites' competition for prestige and move to a friendly jurisdiction; open science and peer review made it easier for a prince to evaluate immigrating scholars.

For more than three centuries the accumulation of useful or practical knowledge in the Western World has been a monotonic process; we have neither seen stagnation nor reversals that were common in earlier historical settings, for instance in China. Various factors have prevented major reversals: the codification of knowledge through various means, its diffuse possession, competition, and the Western entrepreneurial spirit. David (2007) and Mokyr (2005) both recognize that if their speculations are correct, namely that the $A$ revolution in Western Europe is rooted in political fragmentation prior to the consolidation of the nation state, modern prosperity is a delayed gift to the modern era by West European feudalism and the ruins of the Roman Empire.

The steady increase in $A$ has raised living standards in a major way but only for one segment of the human population, the inhabitants of the industrial countries. The gap between rich and poor countries is a measure of our limited knowledge and control of social technologies. Relative to the growth in $A$, social science knowledge has grown at a modest pace in the last 300 years. We understand only imperfectly how power politics and inhospitable social institutions block economic progress and make some countries fall behind. Even less is known about appropriate social technologies for reforming imperfect institutions and neutralizing destructive

11 Scientists were also hired for outright practical purposes. They were sought for technical contributions or problem solving, for instance, in military engineering, hydraulic engineering (canals, irrigation systems, aqueducts), navigation, and the new scientific cartography. Information asymmetry between agents and patrons was also increasing in practical applications of science (David, 2007). 
political systems. There is a fundamental uncertainty about possibilities and limits of reform.

\section{Fickle, Flighty A: Lessons from the Second Industrial Revolution 1860-1900}

In this section I discuss two important lessons from the Second Industrial Revolution. First I briefly introduce the dramatic experience of England toward the end of the $19^{\text {th }}$ Century when the country lost its industrial leadership. The other lesson concerns the uncertain and delayed impact of general-purpose technologies caused by time lags in discovering and implementing useful applications. Electricity and digital electronics are prime examples of general-purpose technologies, representing two different epochs.

To maintain worldwide leadership in $A$ over a span of several generations a country requires not only foresight but also and above all adaptable social institutions. In the early stages of an industrial and technological revolution special interests typically emerge and gradually acquire enough power and authority to safeguard the status quo. These forces see it in their interest to oppose new industrial developments that could undermine their economic base. Economic success can also make the political and industrial leadership of a country complacent and inattentive to new opportunities. During the so-called Second Industrial Revolution 1860-1914, social rigidities and complacency swiftly and unexpectedly deprived England of its leadership in $A$ and gave it to Germany and the United States.

Consider the new chemical industries that played a critical role in the Second Industrial Revolution. Alfred DuPont Chandler, Jr. (1992), sometimes considered the father of modern business history, has examined how England lost its leadership in synthetic dyes. British scientists and entrepreneurs pioneered the technology for synthetic dyes and the huge British textile industry was the largest market in the world for dyes. The production of synthetic dyes required high quality coal and Britain was the largest supplier in Europe of this input. In the 1870s the new dye industry in Britain had almost every advantage. Germany, however, was more flexible, relying on foresighted cooperation between industry, government and technical universities. The provision of appropriate technical education was one of the key elements in Germany's success; novel business organization (new social technology) was another. By 1900 the leadership in synthetic dyes had moved to Germany. In 1913 some 160,000 tons of dyes were produced worldwide. Thereof German firms made 140,000 tons or 88 percent. The British produced only 4,100 tons (Chandler 1992, 90-91). The synthetic dyes story and countless similar lessons tell us that $A$ is a fickle visitor.

Industrial revolutions involve both limited-purpose and general-purpose technologies. The discovery of potential applications of new general-purpose technologies and their implementation is a long process that usually spans decades. The lags between invention and application are caused by many factors, including long and uncertain learning processes, high adjustment costs, and perhaps mental inertia. Electric power, a general-purpose technology, is the symbol of the Second Industrial Revolution. Historians of electricity have established that in the United States it took about half a century of innovations and costly investments before electricity had made its full impact on productivity. For instance, prior to 
electrification factories relied on the power of water or steam, which usually involved a centralized power source. Electric power made it often efficient for factories to equip each machine with its own electric motor, which provided opportunities for reorganizing the entire layout of the production process. The adjustments could be very costly, requiring new factory buildings and major learning and training efforts by management and workers (Devine, 1983; David, 1990).

\section{Whither A? Are we in the early stages of a new industrial revolution?}

The last half of the $20^{\text {th }}$ century saw major innovations that include both specific and general-purpose technologies. It is often said that new information and communication technology is the symbol of our era but, as often before, we do not really know where we are heading. Are we at the dawn of an economic revolution, somewhat like the innocent Adam Smith was at the end of the $18^{\text {th }}$ century, or is recent talk about the Knowledge Economy only empty words? Robert Solow (1987, 2002) has said: "You can see the computer age everywhere but in the productivity statistics." 12 Was he right?

History tells us that the impact of an $A$ revolution is not limited to raising $y$, average output per worker. Revolutionary new technology lowers costs and raises the quality of many existing products, gives us new goods and services, and transforms the organization of business, politics, and social affairs. The new information technology gathered momentum in the last decades of the 20th Century and is gradually transforming a variety of products and industries, ranging from automobiles to biotechnology. The distinguished economist Robert Gordon (2000) argues that recent changes in $A$ are qualitatively less significant than the inventions of the Second Industrial Revolutions, 1860-1914, which profoundly changed living conditions in the West with novelties such as electricity, the telephone, radio, and the internal combustion engine. Is Gordon right? Can he forecast what innovations in commodities and organization the next half-century will bring? I doubt it. In fact, economists and other social scientists can do little more than speculate about marginal changes in technologies, products, and organization. In recent decades various studies have emerged that tentatively examine implications of the new information technology. I conclude by introducing a few research questions that the new $A$ has inspired.

In advanced industrial countries the structure of property rights is usually clearly defined, well enforced and relatively efficient. Major technological change, however, may require substantial revision of property rights in significant sectors of the economy; adjustments to new and uncertain circumstances that often involve trial by error. Intellectual assets are non-rival in use; they often involve huge fixed or set-up costs (for instance genetics-based drugs or computer software) but low (often close to zero) marginal costs of reproduction. An optimal regime for intellectual property must solve a complicated dilemma: to create incentives for the inventors of knowledge assets, for instance through patents (monopoly rights), and also secure

12 Solow made this famous statement in New York Review of Books on July 12 1987. In a 2002 interview in The Region, a publication of the Federal Reserve Bank of Minneapolis, Solow had not changed his mind. 
efficient allocation of the knowledge assets through pricing close to marginal costs (competitive conditions). Posner (2005) argues convincingly that the task of creating optimal regime for intellectual property goes far beyond our cognitive capacities. ${ }^{13}$ Posner is more optimistic about the capacity of scholars to evaluate marginal changes in intellectual property regimes: whether particular changes are likely to increase or decrease the efficiency of the system.

The recent extension of patents to basic research, even to research undertaken in laboratories at publicly funded universities, has created intense controversy among experts. The critics of recent laws extending patent rights claim that over-patenting will create anticommons effects, a problem that is symmetric to the well-known open commons effects that involve waste through over-utilization of resources (Eisenberg and Heller, 1998; Buchanan and Yoon, 2000). The anticommons condition involves excessive property rights and occurs when a large number of owners hold various rights to the same asset and potential users cannot make efficient use of the resource because of high transaction costs in acquiring the necessary rights. ${ }^{14}$ In theory and depending on the cost of transacting, it is sometimes possible for firms to act strategically and limit the anticommons effects of new laws and regulations. The literature provides evidence of firms in the biotechnology industry that have actually invested in antiproperty by organizing open access commons for patentable findings in their sector, particularly for potential inputs located upstream in the production chain (Merges, 2004).

Rapid technical change can also challenge the system of property rights by suddenly creating strong demand for resources that until recently had little commercial value and were therefore not subject to clearly specified property rights. In these situations new legislation or judicial rulings often have vast implications for new industries, and those implications are not always well understood ex ante. The biogenetics industry, it is often claimed, owes its existence in no small part to divided court decisions concerning ownership of biological materials. ${ }^{15}$

Network industries with scale economies on the demand side are relatively common among the new growth industries (Varian, Farrell, \& Shapiro, 2005). With strong demand-side economies of scale, the demand curve for the output has initially an upward slope because the commodity becomes more valuable as more customers use it. These conditions hold for computer operating systems but also for fax machines. Economic analysis shows that in network industries welfare may fall as the number of new entrants increases, if the products of the various firms are incompatible in use. In these industries competition for the market becomes more important for welfare than competition in the market. Standardization is also a question of great

13 An optimal intellectual property regime would probably require a large number of subsystems designed separately for each type of knowledge assets.

14 Heller (1998) was the first to develop the anticommons concept in a paper entitled "The Tragedy of the Anti-Commons: Property in the Transition from Marx to Markets." In developing the concept, Heller was inspired by the puzzle of empty storefronts and full kiosks in Moscow during the early and mid-1990s.

15 See essays by various authors in Ginsburg and Dreyfuss eds. (2006), Intellectual Property Stories. 
importance. The special features of the new network industries seem to call for some rethinking of standard competition and antitrust policy (Economides, 2006).

The economics of Internet markets is an emerging field of research (Ellison and Ellison, 2005). It is reasonable to ask, for instance, whether exchange on the Internet or exchange in the regular market place more resembles the model of perfect competition. We may also want to know whether Internet marketing is likely to enable fine-tuned price discrimination or whether through anonymity it protects buyers who belong to social groups that traditionally pay relatively high prices, for instance for new automobiles or groceries. When combined with the Internet, digitalization of music, pictures and printed matter creates a whole range of issues concerning adjustments in property rights and business organization. The new technology has rekindled passionate debates about private, public and communal ownership, a common theme during the Second Industrial Revolution, although now the debate focuses on knowledge assets and not on coal and steel factories. Many scholars worry about privacy issues; whether digital technology in the hands of the state or large corporations will eventually undermine our privacy and freedom (Benkler, 2006). Concurrently, diligent bloggers invite the world into their personal life.

The new technology also raises new questions in economic geography, for instance about urbanization and location of industry. The British Industrial Revolution introduced centralized manufacturing plants; for most people it separated the home from the workplace; and it moved workers from rural areas into urban centers, depopulating the countryside. Theoretically the new information and communications technology may gradually reverse the urbanization trend and send substantial part of the workforce back home and into rural areas, away from the cities. Relocation to the home and away from offices, factories and other external work places is an efficient alternative only for workers who can work at home approximately as effectively as they now do in centralized workplaces. Such relocation is obviously not an option for all job categories; for instance, most service employees cannot work at home. For potential home workers the critical question is whether new communication technologies, such as the Internet and video conferencing, substitute effectively for the synergy of direct contacts when joint tasks are involved (Leamer \& Storper, 2001). The answer depends on the psychology of learning and group dynamics but also on the quality of the communications technology, social norms and the nature of joint tasks. ${ }^{16}$ Those who are able and willing to work at home may or may not desire to relocate outside major urban areas. The decision to leave the city depends in part on how the new communication technology affects the relative costs and benefits of living (and consuming) in rural and urban areas. The Internet, for instance, can provide various forms of entertainment in remote areas but it can also make consuming in the city more efficient and enjoyable, for instance through homepages of restaurants, theaters, and specialty stores (Sinai \& Waldfogel, 2003). Finally, the new technology affects economic geography on a global scale by lowering the cost of outsourcing across

16 The new technology raises of course questions about reorganization of education and the extent to which the new communications technology can effectively replace the classroom. 
national borders. The economic, political and social consequences of the recent Globalization are only partly understood.

\section{Conclusion}

The unbearable lightness of $A$ blurs our vision of the road ahead. We can see the big picture only when looking back and then not very clearly. Yet it is obvious, to cite the Chinese, that we live in interesting times.

\section{Bibliography}

Ashton, T. S. (1997 [1964]). The Industrial Revolution 1760-1830. Oxford: Oxford University Press.

Benkler, Y. (2006). The Wealth of Networks: How Social Production Transforms Markets and Freedom. New Haven, CT: Yale University Press.

Buchanan, J. M., \& Yoon, Y. J. (2000). Symmetric Tragedies: Commons and Anticommons. Journal of Law and Economics, 43(1), 1-13.

Chandler, A. D. (1992). Organizational Capabilities and the Economic History of the Industrial Enterprise. Journal of Economic Perspectives, 6(3), 79-100.

David, P. A. (1990). The Dynamo and the Computer: A Historical Perspective on the Modern Productivity Paradox. The American Economic Review, 80(2), 355-361.

David, P. A. (2007). The Historical Origins of "Open Science". An Essay on Patronage, Reputation, and Common Agency Contracting in the Scientific Revolution. Stanford University and University of Oxford. Stanford: Working Paper.

Devine, W. D. (1983). From Shafts to Wires: Historical Perspectives on Electrification. Journal of Economic History, 43(2), 347-372.

Economides, N. (2006). Public Policy in Network Industries. Law and Economics Research Paper, New York University, School of Law, New York.

Eggertsson, T. (2005). Imperfect Institutions: Possibilities and Limits of Reform. New York: Cambridge University Press.

Ellison, G., \& Ellison, S. F. (2005). Lessons about Markets from the Internet. Journal of Economic Perspectives, 19(2), 139-158.

Ginsburg, J. \& Dreyfuss, R. (2006). Intellectual Property Stories. New York, NY: Foundation Press.

Gordon, R. J. (2000). Does the New Economy Measure up to the Great Inventions of the Past? The Journal of Economic Perspectives, 14(4), 49-74.

Heller, M. A. (1998). The Tragedy of the Anticommons. Property in the Transition from Marx to Markets. Harvard Law Review, 111(3), 622-688.

Heller, M. A., \& Eisenberg, R. S. (1998). Can Patents Deter Innovation? The Anticommons in Biomedical Research. Science, 280, 698-701.

Hull, B. B. \& Bold, F. (1994). Hell, Religion and Cultural Change. Journal of Institutional and Theoretical Economics, 150, 447-464. 
Koebner, R. (1959). Adam Smith and the Industrial Revolution. Economic History Review, 11, 381-391.

Kronick, D. A. (1961). Scientific and Technical Periodicals of the Seventeenth and Eighteenth Centuries. Lanham, MD: Scarecrow Press.

Leamer, E. E. \& Storper, M. (2001). The Economic Geography of the Internet Age. Cambridge, MA: National Bureau of Economic Research.

Machlup, F. (1962). The Production and Distribution of Knowledge in the United States. Princeton, NJ: Princeton University Press.

Merges, R. P. (2004). A New Dynamism in the Public Domain. University of Chicago Law Review, 71, 183-203.

Merton, R. K. (1973). The Sociology of Science. Chicago, Ill: University of Chicago Press. Mokyr, J. (2005a). The Intellectual Origins of Modern Economic Growth. The Journal of Economic History, 65(2), 285-351.

Mokyr, J. (2005b). Mobility, Creativity, and Technological Development: David Hume, Immanuel Kant and the Economic Development of Europe. Working Paper. Evanston, Ill: Departments of Economics and History, Northwestern University.

Nelson, R. R. (1997). The Agenda for Growth Theory: A Different Point of View. Cambridge Journal of Economics, 22, 497-520.

Nelson, R. R., \& Winter, S.G. (1982). An Evolutionary Theory of Economic Change. Cambridge, MA: Harvard University Press.

Posner, R. A. (1980). A Theory of Primitive Society, With Special Reference to Law. Journal of Political Economy, 23 (1), 1-53.

Posner, R. A. (2005). Intellectual Property: The Law and Economics Approach. Journal of Economic Perspectives, 19 (2), 57-73.

Romer, P. M. (1994). The Origins of Endogenous Growth. Journal of Economic Perspectives, 8(1), 3-22.

Schumpeter, J. A. (2005 [1939]). Business Cycles: A Theoretical, Historical, and Statistical Analysis of the Capitalist Process, 2 vol. Martino Pub.

Sinai, T. \& Waldfogel, J. (2003). Geography and the Internet: Is the Internet a Substitute or a Complement for Cities? Cambridge, MA: National Bureau of Economic Research.

Solow, R. M. (1956). A Contribution to the Theory of Economic Growth. Quarterly Journal of Economics, 70, 65-94.

Solow, R. M. (1957). Technical Change and the Aggregate Production Function. Review of Economics and Statistics, 39, 312-320.

Varian, H. R., Farrell, J. \& Shapiro, C. (2005). The Economics of Information Technology: An Introduction. New York, NY: Cambridge University Press.

Westfall, R. S. (1985). Science and Patronage: Galileo and the Telescope. Isis , 76, 1130. 
